九州大学学術情報リポジトリ

Kyushu University Institutional Repository

Notes on the Lure Responsiveness of Fruit Flies of the Tribe Dacini (Diptera: Tephritidae) in Sri Lanka

Tsuruta, Kenj i

Ministry of Agriculture, Forestry and Fisheries

Bandara, H. M. J.

Seed Certification \& Plant Protection Centre

Rajapakse, G. B. J. P

National Plant Quarantine Service

https://doi.org/10.5109/2707

出版情報: ESAKIA. 45，pp.179-184，2005-03-31. Entomological Laboratory，Faculty of Agriculture, Kyushu University バージョン：

権利関係 : 


\title{
Notes on the Lure Responsiveness of Fruit Flies of the Tribe Dacimi (Diptera: Tephritidae) in Sri Lanka
}

\author{
Kenji TsURUTA \\ Narita Sub-station, Yokohama Plant Protection Station, Ministry of Agriculture, \\ Forestry and Fisheries, Narita, Chiba, 282-0021 Japan
}

H. M. J. BANDARA

Seed Certification \& Plant Protection Centre, Gannoruwa, Sri Lanka

and

\section{G. B. J. P. RAJAPAKSE}

National Plant Quarantine Service, Katunayake, Sri Lanka

\begin{abstract}
Twenty-four dacine fruit fly species were recorded in a lure trapping survey in Sri Lanka. The number of species attracted by a cue lure (CL) or methyl eugenol (ME), and those that didn't respond to either but were recorded in a fruit collection survey, were 17,7 , and 6 , respectively. These records and the distribution of responsiveness among dacine fruit flies of Sri Lanka according to the existing classification were investigated. The results showed that those that responded to $\mathrm{ME}$ were distributed in only one genus, Bactrocera (Bactrocera), while those that responded to CL were distributed widely across different genera and subgenera: Bactrocera (subgenera Afrodacus, Bactrocera, Zeugodacus, Javadacus, and Parazeugodacus), and Dacus (Callantra). The results were consistent with the general tendency of responsiveness among Dacini. The ratio of species that responded to CL and those that responded to ME was about 2.4: 1 .
\end{abstract}

Key words: Fruit fly, Dacini, Bactrocera, Dacus, lure response, Sri Lanka

1) Contribution from the Entomological Laboratory, Faculty of Agriculture, Kyushu University, Fukuoka (Ser. 6, No. 15). 


\section{Introduction}

Fruit flies of the tribe Dacini Bezzi are characterized not only by morphological characters, but also behavioral (physiological) characters such as their responsiveness to male lures. By using these characters, many faunal as well as population surveys have recently been conducted in various countries in Asia and Australasia (Drew, 1989; Drew \& Hancock, 1994; Allwood et al., 1997; Tsuruta \& White, 2001; Drew \& Raghu, 2002). Responses to male lures are also useful for identification, because of the consistency in responsiveness among species to a single fixed lure in principle.

The present authors conducted fruit fly faunal surveys in Sri Lanka using lure-baited traps during the period of 1993-1996. Before this survey, comprehensive lure response data had not been reported for Sri Lanka; the results include many new taxon-specific lure records. In this paper, all lure response data recorded and the distribution of lure responsiveness among all known members of Dacini fruit flies in Sri Lanka are given.

\section{Materials and Methods}

Fruit flies of the tribe Dacini were collected in Steiner-type traps baited with cue lure (4- [4(acetyloxy) phenyl] -2-butanone; CL) or methyl eugenol (1,2-dimethoxy-4-(2-propenyl) benzene; ME). About 40 permanent as well as numerous temporary trapping sites covering almost all agro-ecological regions were selected. In addition to the lure trapping surveys, collection of infested fruits and vegetables were also made to obtain records of those species that did not respond to the lures. The tribal, generic, and subgeneric classifications, including subgeneric groups, followed that of Drew (1989).

\section{Results}

A total of 24 species were recorded in the lure trapping survey, and of these, 17 responded to $\mathrm{CL}$ and 7 to ME. In addition, 6 species were recorded in the fruit collection survey, but not the trapping survey. All are listed in Table 1. The distribution of lure responsiveness among all known fruit flies in Sri Lanka was arranged in accordance with an existing classification as listed in table 2 .

\section{Discussion}

Lure responsiveness is a relatively stable taxonomic character. Furthermore, it is interesting to examine how responsiveness to a single kind of lure in principle or non-responsiveness is determined through phylogenetic diversification. 
Table 1. Fruit flies recorded by trapping or during fruit collection surveys in Sri Lanka

\begin{tabular}{|c|c|c|}
\hline \multicolumn{3}{|l|}{ Lure } \\
\hline Methyl eugenol & $\begin{array}{l}\text { Bactrocera } \\
B . \\
B . \\
B . \\
B . \\
B . \\
B .\end{array}$ & $\begin{array}{ll}(B . & \text { ) apicofuscans White et Tsuruta } \\
(B . & \text { ) correcta (Bezzi) } \\
(B . & \text { ) dorsalis (Hendel) } \\
(B . & \text { ) kandiensis Drew et Hancock } \\
(B . & \text { ) paraverbascifoliae Drew } \\
(B . & \text { ) versicolor (Bezzi) } \\
(B . & \text { ) zonta (Saunders) }\end{array}$ \\
\hline Cue lure & $\begin{array}{l}B . \\
B . \\
B . \\
B . \\
B . \\
B . \\
B . \\
B . \\
B . \\
B . \\
B . \\
B . \\
B . \\
B . \\
B . \\
\text { Dacus } \quad(\text { Cal } \\
\text { D. } \\
\text { B. C. }\end{array}$ & $\begin{array}{ll}\text { (Afrodacus } & \text { ) fastigata Tsuruta et White } \\
(B . & \text { ) brunneola White et Tsuruta } \\
(B . & \text { ) ceylanica Tsuruta et White } \\
(B . & \text { ) fernandoi Tsuruta et White } \\
(B . & \text { ) hantanae Tsuruta et White } \\
(B . & \text { ) nigrofemoralis White et Tsuruta } \\
(B . & \text { ) perigrapha White et Tsuruta } \\
(B . & \text { ) profunda Tsuruta et White } \\
(B . & \text { ) selenophora Tsuruta et White } \\
\text { (Javadacus }) \text { trilineata (Hardy) } \\
\text { (Zeugodacus) caudata (Fabricius) } \\
(Z . & \text { ) cucurbitae (Coquillett) } \\
(Z . & \text { ) duplicata (Bezzi) } \\
(Z . & \text { ) gavisa (Munro) } \\
(Z . & \text { ) zahadi Mahmood } \\
\text { lantra }) \text { discophorus (Hering) } \\
& \text { ) ramanii Drew et Hancock }\end{array}$ \\
\hline Non-responding & $\begin{array}{l}\text { known lure } \\
B . \\
B . \\
B . \\
B . \\
D . \\
D . \\
\end{array}$ & 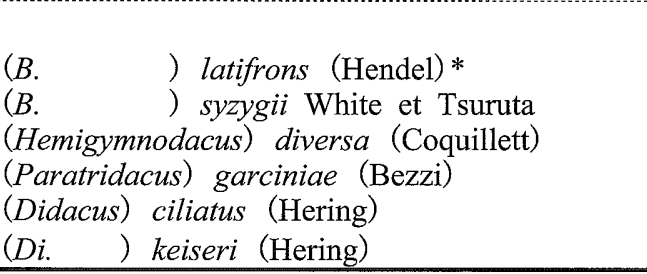 \\
\hline
\end{tabular}

* : A synthetic lure is known for this species, but was not used in our survey.

Some taxonomic groups, defined by morphological characters, have positive associations with specific kinds of lures; for example, species of the subgeneric group Zeugodacus generally respond to $\mathrm{CL}$, except for the non-responding species, B. (Hemigymnodacus) diversa and B. (Paratricdacus) garciniae. Among species of Dacus, responsiveness differs in each species of the same subgenus; in the subgenus Callantra, for example, $D$. (C.) ramanii positively responds to $\mathrm{CL}$, while $D$. (C.) discophorus rarely does so. Among members of Bactrocera subgeneric groups, there are species that respond to CL and ME, and those that don't respond to either. The responsiveness of each species is clearly different even among morphologically very similar species such as members of the $B$. dorsalis species complex; for example, $B$. dorsalis, $B$. kandiensis and $B$. paraverbascifoliae respond to ME, while $B$. fernandoi, B. profunda, B. hantanae, and B. fastigata respond to CL. In addition, in the $B$. 
zonata species group, which represents three species, all members respond to ME. These results are completely consistent with the summary of general tendency of responsiveness among Dacini given by Drew \& Hancock (2000).

In addition to these lure responding species there are several species that were recorded only in the fruit collection survey. Bactrocera. (B.) latifrons, B. (B.) syzygii, B. (Paratridacus) garciniae, B. (Hemigymnodacus) diversa, D. (Didacus) ciliatus and D. (Di.) keiseri were recorded in the fruit collection survey, but not the trapping survey (Tsuruta et al., 1997; Tsuruta \& White, 2001), and D. (Leptoxyda) persicus, which occurs in Sri Lanka was recorded neither in the lure tapping nor the fruit collection surveys. Most individuals of $D$. (C.) discophorus were obtained in the fruit collection survey, but only a single individual was captured in the trap baited with CL, thus the responsiveness of this species seems to be very weak at best.

\section{Distribution of lure responsiveness}

Of the Sri Lankan dacine fruit flies, those that responded to ME were found only in the subgenus Bactrocera, while those that responded to CL were recorded across many different taxonomic groups, such as the Bactrocera subgeneric groups including subgenera, Afrodacus and Bactrocera, and the Zeugodacus subgeneric groups including subgenera, Zeugodacus, Javadacus, and Parazeugodacus, and the species of different genus and subgenus such as Dacus (Callantra). These facts generally support the view that "Cuelure ...... may represent the "primitive' lure for both Dacus and Bactrocera" (Drew \& Hancock, 2000).

The ratio of species that respond to $\mathrm{ME}$ and those that respond to $\mathrm{CL}$ among all known species of Dacini worldwide is about 3: 1 (White, 2000), while the ratio obtained in Sri Lanka (2.4: 1$)$ is a little smaller. However, this ratio is regarded as reasonable because the trapping surveys did not adequately cover natural vegetation areas where species that respond to CL are generally abundant.

\section{Taxonomic notes}

Although the subgenus Hemigymnodacus was considered a synonym of Paratridacus in a recent catalogue (Norrbom, A.L. et al., 1998), it has been used to classify B. diversa following Delfinado \& Hardy (1977). According to White (2000), this species responds to ME, but it has yet to be recorded in our lure trapping surveys, although it has been collected from flowers of cultivated cucurbits. Furthermore, B. bipustulata is placed in the subgenus Zeugodacus according to the recent catalogue (Norrbom et al., 1998), but we placed this species in the subgenus Parazeugodacus following Delfinado \& Hardy (1977).

It is hoped that more surveys in various other geographical regions will be conducted using male lures, thus adding to the taxon-specific lure records and enabling further analysis of the phylogenetic relationships of lure responsiveness among species of Dacini. This will also be 
Table 2. Distribution of lure responsiveness in dacine fruit flies of Sri Lanka

\begin{tabular}{|c|c|}
\hline Species & Lure \\
\hline \multicolumn{2}{|l|}{ Genus Bactrocera Macquart } \\
\hline \multicolumn{2}{|l|}{ Bactrocera group of subgenera } \\
\hline \multicolumn{2}{|l|}{ Subgenus Afrodacus Bezzi } \\
\hline Bactrocera (Afrodacus) fastigata Tsuruta et White & $\mathrm{CL}$ \\
\hline \multicolumn{2}{|l|}{ Subgenus Bactrocera Macquart } \\
\hline \multicolumn{2}{|l|}{$\begin{array}{l}\text { Species placed in complex } \\
B \text {. dorsalis species complex }\end{array}$} \\
\hline B. caryeae (Kapoor) & ME* \\
\hline B. ceylanica Tsuruta et White & $\mathrm{CL}$ \\
\hline B. dorsalis (Hendel) & ME \\
\hline B. fernandoi Tsuruta et White & CL \\
\hline B. hantanae Tsuruta et White & CL \\
\hline B. kandiensis Drew et Hancock & $\mathrm{M}$ \\
\hline B. paraverbascifoliae Drew & M \\
\hline B. profunda Tsuruta et White & $\mathrm{CL}$ \\
\hline B. syzygii White et Tsuruta & $\mathrm{N}$ \\
\hline \multicolumn{2}{|l|}{ B. zonata species group } \\
\hline B. correta (Bezzi) & ME \\
\hline B. versicolor (Bezzi) & $\mathrm{ME}$ \\
\hline B. zonata (Saunders) & ME \\
\hline \multicolumn{2}{|l|}{ Species not placed in complex } \\
\hline B. apicofuscans White et Tsuruta & ME \\
\hline B. latifrons (Henel) & $\mathrm{N}$ \\
\hline B. nigrofemoralis White et Tsuruta & $\mathrm{CL}$ \\
\hline B. perigrapha White et Tsuruta & $\mathrm{CL}$ \\
\hline \multicolumn{2}{|l|}{ Zeugodacus group of subgenera } \\
\hline \multicolumn{2}{|l|}{ Subgenus Hemigymnodacus Hardy } \\
\hline B. diversa (Coquillett) & $\mathrm{N}$ \\
\hline \multicolumn{2}{|l|}{ Subgenus Javadacus Hardy } \\
\hline B. trilineata (Hardy) & $\mathrm{CL}$ \\
\hline \multicolumn{2}{|l|}{ Subgenus Paratridacus Shiraki } \\
\hline B. garciniae (Bezzi) & $\mathrm{N}$ \\
\hline \multicolumn{2}{|l|}{ Subgenus Parazeugodacus Shiraki } \\
\hline B. bipustulata (Bezzi) & CL* \\
\hline \multicolumn{2}{|l|}{ Subgenus Zeugodacus Hendel } \\
\hline B. caudata (Fabricius) & $\mathrm{CL}$ \\
\hline B. cucurbitae (Coquillet) & $\mathrm{CL}$ \\
\hline B. duplicata (Bezzi) & $\mathrm{CL}$ \\
\hline B. gavisa (Munro) & $\mathrm{CL}$ \\
\hline B. zahadi Mahmood & $\mathrm{CL}$ \\
\hline \multicolumn{2}{|l|}{ Genus Dacus Fabricius } \\
\hline \multicolumn{2}{|l|}{ Subgenus Callantra Walker } \\
\hline D. discophorus (Hering) & $\mathrm{CL}$ \\
\hline D. ramanii (Drew et Hancock) & $\mathrm{CL}$ \\
\hline \multicolumn{2}{|l|}{ Subgenus Didacus Collart } \\
\hline D. ciliatus (Hering) & $\mathrm{N}$ \\
\hline D. keiseri (Hering) & $\mathrm{N}$ \\
\hline Subgenus Leptoxyda Hendel & \\
\hline D. persicus (Hendel) & $\mathrm{N}^{*}$ \\
\hline
\end{tabular}

* : Entry of these species on this list and their lure data are based on specimens preserved in NHM, London.

CL: Cue lure ME: Methyl eugenol N: Non-responding or No known lure 
helpful for more practical purposes such as identification of fruit flies associated with plant quarantine fields.

\section{Acknowledgements}

The senior author is most grateful to Prof. O. Tadauchi, Entomological Laboratory, Kyushu University, for his constant encouragement. His cordial thanks are also due to Prof. R. A. I. Drew, International Center for Management of Pest Fruit Flies, Griffith University, Brisbane, and D.L. Hancock, Cairns, for their invaluable suggestions given to the senior author during his on-site study in Australia. We thank the Yokohama Plant Protection Station, Ministry of Agriculture, Forestry, and Fisheries, for providing male lures for our trapping surveys.

\section{References}

Allwood, A. J. \& R. A. I. Drew, 1997. Management of fruit flies in the Pacific. ACIAR Proceedings No. 76, $267 \mathrm{p}$.

Delfinado, M. D. \& D. E. Hardy, 1977. A Catalog of the Diptera of the Oriental Region. Vol. 3 Suborder Cyclorrhapha. The University Press of Hawaii, Honolulu.

Drew, R. A. I., 1989. The tropical fruit flies (Diptera: Tephritidae: Dacinae) of Australian and Oceanian Regions. Memoirs of the Queensland Museum, 26: 1-521.

Drew, R. A. I. \& D. L. Hancock, 1994. The Bactrocera dorsalis complex of fruit flies (Diptera: Tephritidae: Dacinae) in Asia. Bull. ent. Res., Suppl. No.2: 1-68.

Drew, R. A. I. \& D. L. Hancock, 2000. Phylogeny of the Tribe Dacini (Dacinae) based on morphological, distributional, and biological data. In Aluja, M. \& A. L. Norrbom (eds.), Fruit Flies (Tephritidae): Phylogeny and Evolution of Behavior. CRC Press LLC, New York.

Drew, R. A. I. \& S. Raghu, 2002. The fruit fly fauna (Diptera: Tephritidae: Dacinae) of the rainforest habitat of the Western Ghats, India. Raffles Bull. Zool., 50 (2): 327-352.

Norrbom, A. L., L. E. Carrol, F. C. Thompson, I. M. White, \& A. Freidberg, 1998. Systematic Databases of Names. In Thompson, F.C. (ed.), Fruit Fly Expert Identification System and Systematic Information Database. Myia 9. Backhuys Publishers.

Tsuruta, K \& I. M. White, 2001. Eleven new species of the genus Bactrocera (Diptera: Tephritidae) from Sri Lanka. Ent. Sci., 4: 69-87.

Tsuruta, K., I. M. White, H.M.J. Bandara, H. Rajapakse, S. A. H. Sundaraperma, S. B. M. U. C, Kahawatta \& G. B. J. P. Rajapakse, 1997. A preliminary note on the host-plants of fruit flies of the tribe Dacini (Diptera, Tephritidae) in Sri Lanka. Esakia, 37: 149-160.

White, I.M., 2000. Morphological features of the tribe Dacini (Dacinae): Their significance to behavior and classification. In Aluja, M. \& A. L. Norrbom, (eds.), Fruit Flies (Tephritidae): Phylogeny and Evolution of Behavior. CRC Press LLC, New York. 